\title{
Transterminologization in the Aerology and Ventilation term System
}

\author{
Anna A. Teleguz and Andrei G. Fomin* \\ Kemerovo State University \\ 6 Krasnaya Str., Kemerovo, 650043, Russia
}

Received 03.10.2015, received in revised form 30.10.2015, accepted 29.11.2015

\begin{abstract}
Aerology and ventilation term system has developed on the basis of mining, chemical, physical, geological and some other term systems. For that reason it borrowed many terms from them. But in many cases the process of transterminologization was accompanied by the change of meaning. The seme composition of terms can alter in different ways. For example, the most frequent change of meaning occurs when distinctive semes are replaced by other ones, relevant for the accepting term system. In some cases there can be a change of archiseme, while some distinctive semes remain intact. The change of entire seme composition takes place rather seldom. Explicit transterminologization, when a term acquires a new definition, is less common for aerology and ventilation term system than implicit transterminologization. In the latter case borrowed terms do not acquire new definitions, but the structure of the microfield they enter differs considerably from the one they have been taken from.
\end{abstract}

Keywords: implicit and explicit transterminologization, archiseme, seme composition, distinctive seme, aerology.

DOI: 10.17516/1997-1370-2015-8-12-2960-2969.

Research area: philology.

\section{Introduction}

The extension of scientific knowledge, more active interaction between sciences and diversification and strengthening of connections between the terms, which belong to different term systems, resulted in borrowing terms from one term system to another. This process is known as transterminologization. As a result of term borrowing from one system into another, interdisciplinary homonyms are formed (Superanskaia, et al., 2012, p. 203). Moreover, this process results in different semantic changes
(Ryzhenkova, 2001). In that case the ground for term borrowing is the term system of another science, not the literary language (Baranov, 2003).

\section{Peculiarities of transterminologization}

in aerology and ventilation term system

The term analysis has shown that the main part of the terms which came to the aerology and ventilation term system as a result of transterminologization were borrowed from mining, geological, and chemical term systems.

(c) Siberian Federal University. All rights reserved

* Corresponding author E-mail address: andfomin67@mail.ru, annateleguz@ya.ru 
That is quite logical, because conceptual systems of these sciences formed the base for aerology and ventilation development, and the conceptual system of aerology and ventilation is reflected by the corresponding term system.

The borrowed terms were subject to either explicit or implicit transterminologization. As a result of explicit transterminologization terms acquired new definitions, which differ from the ones these terms had in the original term system (Ryzhenkova, 2001). Transterminologization of the term каптаж can be a good example of explicit transterminologization. This term was transferred from mining term system.

Каптаж - инженерно-техническое сооружение, обеспечивающее вскрытие подземных вод, нефти или газа, вывод их на поверхность, изоляиию эксплуатачионного горизонта и возможность эксплуатации при соблюдении заданных показателей дебита, состава, температуры и других параметров (Kozlovskii, 1986, p.549).

Каптаж - прочесс улавливания газа в скважины, специиальные газосборные выработки или устройства и вывода его с помощью вакуум-насосов по трубам на поверхность или через диффузор-смеситель в вентиляционную выработку (Instriktsiia po Degazatsii..., 2012, p. 46).

In this example a new archiseme "capture process" replaced the original one "construction", which became a distinctive seme of the aerological term. But the seme "removal to the surface" remained intact, and the seme "water, oil, gas handling" narrowed to "gas handling" (Table 1).

Transterminologization of the term дренаж / drainage in both languages resulted in the full change of seme composition. The given terms are used in both geological and mining term systems.

Дренаж - естественное или искусственное осушение водоносных горных пород-сток воды в естественные понижения (реки, озера и др.) или искусственные сооружения (каналы, колодиы, шахты и др.) (Paffengolts, 1978, c. 239).

Дренаж - способ осушения территории месторождений полезных ископаемых, массивов горных пород путем сбора и отвода подземных гравитационных вод в естественные понижения (реки, озера и т.п.) или искусственные сооружения (каналь, горные выработки и др.) (Kozlovskii, 1986, c.266).

Газовый дренаж - удаление газа из угольных пластов и пород по естественным или искусственным каналам (Instriktsiia ро Degazatsii..., 2012, p. 43) (Table 2).

As a result of transterminologization, there was the following archiseme change: "draining"/ "draining method" $\rightarrow$ "gas removal".

In the mentioned example there is only one homonymous seme, which remained intact, which is "the use of artificial or natural constructions". But in the last case it denotes air passages (which are used to move gas from one place to another),

Table 1

\begin{tabular}{|l|l|}
\hline \multicolumn{1}{|c|}{ Mining } & \multicolumn{1}{c|}{ Ventilation } \\
\hline Archiseme - construction & Archiseme - capture process \\
Seme - removal to the surface & Seme - removal to the surface \\
Seme - water, oil, gas handling & Seme - gas handling \\
Seme - operation at special parameters & Seme - collection and removal using special \\
Seme - mining level isolation & ventilation appliances \\
\hline
\end{tabular}


while in the other two water-lowering sumps or water-absorbing wells are implied (where, in the end, water is collected).

Besides, transterminologization lead to the change of seme, which denoted the movement direction. Water flows to lower places in the first two cases, while in the last case gas is removed to the surface, which is situated upward from the gas source. But this did not find any explicit expression in the definition of the term газовый дренаж. The direction of removal can be identified if we consider the definition of the term газодренажная выработка:

Газодренажная выработка неконтролируемая выработка специального назначения, ... служащая для перемещения метановоздушной смеси от выработанного пространства действуюших выемочных участков до поверхности или вентиляиионной скважиньl (Instriktsiia po Degazatsii..., 2012, p. 14).
The situation is almost the same in the case of the term drainage transterminologization:

Drainage - the manner of gravity flow of water or the process of channelization, for removal at a point remote from a mining operation (Dictionary of Mining..., 1996, p. 979).

Gas drainage - methods for capturing the naturally occurring gas in coal seams to prevent it entering mine airways. The gas can be removed from coal seams in advance of mining using pre-drainage techniques and from coal seams disturbed by the extraction process using postdrainage techniques (Best Practice Guidance..., p. xii) (Table 3).

First of all, the archiseme changed. Moreover, in the source term system the term gas drainage had a seme in its seme composition which denoted the movement direction.

Gravity flow - the flow of water drawn through a conduit under the force of gravity (The Free Online Dictionary).

Table 2

\begin{tabular}{|c|c|c|}
\hline Geology & Mining & Ventilation \\
\hline $\begin{array}{l}\text { Archiseme - draining } \\
\text { Seme - water handling }\end{array}$ & $\begin{array}{l}\text { Archiseme - draining method } \\
\text { Seme - underground gravity water } \\
\text { handling }\end{array}$ & $\begin{array}{l}\text { Archiseme - gas removal } \\
\text { Seme - gas handling }\end{array}$ \\
\hline $\begin{array}{l}\text { Seme - water-bearing rock is } \\
\text { affected } \\
\text { Seme - downward movement } \\
\text { Seme - usage of artificial / natural } \\
\text { constructions (water reservoirs / } \\
\text { wells / pits) }\end{array}$ & $\begin{array}{l}\text { Seme }- \text { territories with deposits } \\
\text { and rock are affected } \\
\text { Seme - } \text { downward movement } \\
\text { Seme - usage of artificial and } \\
\text { natural constructions (water } \\
\text { reservoirs / wells / pits) }\end{array}$ & $\begin{array}{l}\text { Seme }- \text { the sources are coal seams } \\
\text { and rock } \\
\text { *Seme - upward movement } \\
\text { Seme - usage of artificial and } \\
\text { natural constructions (passages) }\end{array}$ \\
\hline
\end{tabular}

Table 3

\begin{tabular}{|l|l|}
\hline \multicolumn{1}{|c|}{ Mining } & \multicolumn{1}{|c|}{ Ventilation } \\
\hline Archiseme - manner of gravity flow of water & Archiseme - methods for capturing gas \\
Seme - process of channelization & Seme - removal \\
Seme - removal & Seme - capturing \\
Seme - remote from a mining operation & Seme - prevention of entering mine airways \\
$*$ Seme - downward movement & \\
\hline
\end{tabular}


Gravity $\mathrm{n}[\mathrm{U}] 1$ technical the force that causes something to fall to the ground or to be attached to another planet (Longman Dictionary..., 2001, p. 622).

Thus, water flows down because of gravity.

As for the definition of the term gas drainage, there is no seme, which denotes the movement direction.

The seme removal stays, but another seme "capturing" is added.

Capture n. [U] 1 the act of catching someone in order to keep him/her as a prisoner. 2 the act of getting control of something (Longman Dictionary..., 2001, p. 141).

Remove v. [T] 1 to take something away from, out of, or off the place where it is (Longman Dictionary..., 2001, p. 856).

According to the considered definitions for the aerology and ventilation term systems both gas removal and gas capture are very important.

The next term firedamp came from the mining term system. In aerology and ventilation term system the term acquired a new definition, which reflected the widening of the term meaning.

Firedamp - a. A combustible gas that is formed in mines by decomposition of coal or other carbonaceous matter and that consists chiefly of methane; also the explosive mixture formed by this gas with air. The term "combustible gases" is now used for firedamp. Webster $3 r d$ b. A stone, brick, or concrete airtight stopping to isolate an underground fire, and to prevent the inflow of fresh air and the outflow of foul air (Dictionary of Mining..., 1996, p.1203).

Firedamp - alternative term for CMM (Best Practice Guidance..., p. xi).

Coal mine methane (CMM) - gas captured at a working coal mine by underground methane drainage techniques. The gas consists of a mixture of methane and other hydrocarbons and water vapour ... Any gas captured underground, whether drained in advance of or after mining, and any gas drained from surface goaf wells is included in this definition (Best Practice Guidance..., p. xi).

In the mining term system the term firedamp denotes a combustible gas, while in the aerology and ventilation term system it denotes any gas, captured in a mine (Table 4).

In the mining term system the term combustible gases replaced the term firedamp.

Not only one-component terms can be subject to transterminologization, but multicomponent ones as well (Ryzhenkova, 2001).

In the aerology and ventilation term system there is a great number of two-component terms, which were borrowed from other term systems. For example, the term газовая съемка came into aerology and ventilation term system as a result of transtermonologization:

Газовая съемка - геохимический метод, основанный на изучении состава природных

Table 4

\begin{tabular}{|l|l|}
\hline \multicolumn{1}{|c|}{ Mining } & \multicolumn{1}{c|}{ Aerology and ventilation } \\
\hline Archiseme 1 - combustible gas in mines & Archiseme - any gas captured underground \\
Seme - explosive mixture formed by this gas with air & Seme - consists of a mixture of methane and other \\
Seme - consists chiefly of methane & hydrocarbons and water vapour \\
Seme - is formed in mines by decomposition of coal & Seme - drainage from surface goaf wells \\
or other carbonaceous matter & Seme - capture at a working coal mine \\
Archiseme 2 - airtight stopping & Seme - underground methane drainage techniques are \\
Seme - isolation of an underground fire & used. \\
\hline
\end{tabular}


газов, мигрирующих до земной поверхности. Проводится с цеелью поисков нефтяных и газовых месторождений, рудных полезных ископаемых..., минеральных вод, а также для геологического картирования (Kozlovskii, 1984, c.482).

Газовая съемка - комплекс работ по установлению параметров распределения газовоздушнойсмесивсетигорныхвыработок или в дегазационной системе (Instriktsiia po Degazatsii..., 2012, p. 42).

The narrowing of the meaning happened as a new aerologic distinctive seme was added. It reflects the goal of the gas survey - "determination of gas-air mixture characteristics" (Table 5).

In English term system the term air lock was also the subject to explicit transterminologization.

Air lock-a. A casing at the top of an upcast shaft to minimize surface air leakage to the fan. $b$. A system of doors arranged to allow the passage of workers or vehicles without permitting appreciable airflow (Dictionary of Mining..., 1996, p. 76).
Air lock - an arrangement of doors that allows passage from one part of a mine ventilation circuit to another without causing a short-circuit (Best Practice Guidance...) (Table 6).

In that case the meaning of the term has narrowed. Only the second archiseme was preserved. Besides, the meaning of the distinctive seme has changed as well. That happened due to the addition of the aerological element ventilation circuit to the distinctive seme.

It should be noted that in the aerology and ventilation term system implicit transtermonologization is spread more widely.

The term метан (methane) in both English and Russian aerological term systems was borrowed from the chemical term system as a result of implicit transterminologization. It did not acquire a new definition in the aerology and ventilation term system, but the structure of the mocrofield it entered differed from the original one considerably.

The term methane was borrowed from organic chemistry term system. There it had evident external systematic features. The suffix $-a \mu$ (-ane) shows that this gas belongs to acyclic

Table 5

\begin{tabular}{|c|c|}
\hline Mining & Aerology and ventilation \\
\hline $\begin{array}{l}\text { Archiseme - geochemical method } \\
\text { Seme - study of natural gas composition } \\
\text { Seme - application to find mineral resources, mineral } \\
\text { water, etc. }\end{array}$ & $\begin{array}{l}\text { Archiseme }- \text { range of works } \\
\text { Seme - determination of gas-air mixture } \\
\text { characteristics } \\
\text { Seme - in mine workings or degassing system }\end{array}$ \\
\hline
\end{tabular}

Table 6

\begin{tabular}{|l|l|}
\hline \multicolumn{1}{|c|}{ Mining } & \multicolumn{1}{|c|}{ Aerology and ventilation } \\
\hline Archiseme 1 - casing at the top of a shaft & Archiseme - arrangement of doors \\
Seme - minimization of surface air leakage to the fan & Seme - allows passage from one part of a mine \\
Archiseme 2 $-\underline{\text { system of doors }}$ & ventilation circuit to another \\
Seme - allows the passage of workers or vehicles & Seme - prevents from a short-circuit. \\
Seme - prevents from appreciable airflow & \\
\hline
\end{tabular}


paraffins (alkanes). The morpheme -aн (-ane) is bound in both languages. It helps to form the names of other alkanes such as бутан / butane, пентан / pentane, гептан / heptane, etc.

But in aerology and ventilation term system it loses its external systematic features, as only four terms were taken to the aerology and ventilation term system, namely метан (methane), этан (ethane), пропан (propane), бутан (butane). The last three terms are used in the aerology and ventilation term system very seldom. The main reason is that these gases occur in mining atmosphere in insufficient quantities compared to methane.

Methane, propane, and hydrogen are also used as standards with which other flammable gases can be compared (Cashdollar et al., p. 1).

The difference in the microfield structure reflects the differences in the conceptual systems of two sciences. In the organic chemistry term system ethane, propane, and butane belong to light hydrocarbons, while in the aerology and ventilation term system they comprise a group of heavy hydrocarbons, as they are heavier than methane, which is considered as the main gas.

For the aerology and ventilation term system other properties of the mentioned gases are more important than for the chemical term system. For example, for chemical term system the molecular structure is of great importance, while for the aerology and ventilation term system pays especial attention to such methane properties as flammability and explosion hazard. In the organic chemistry term system methane is a hyponym to the term alkane, but in aerology and ventilation term system it is a hyponym to the term poisonous gases. This explains the difference in co-hyponyms of the term methane.

Besides, the term метан (methane) in aerology and ventilation term system is used very often, while its chemical formula $\mathrm{CH}_{4}$ is mainly used in equations and definitions, though it is shorter. On the contrary, in organic chemistry term system its formula is used mainly. That also proves the idea that for the aerological conceptual system the physical properties of this gas are of main importance, but not its molecular structure, reflected in its chemical formula.

«При проведении вертикальных выработок (стволов, шурфов) количество воздуха для их проветривания по выделению метана, определяется по формуле... (Gorbunov, 2003, p. 66).

In the aerology and ventilation term system the term methane / метан forms a numerous word family, which consists such terms as метаноносность,

метанообильность,

\section{Organic chemistry term system}

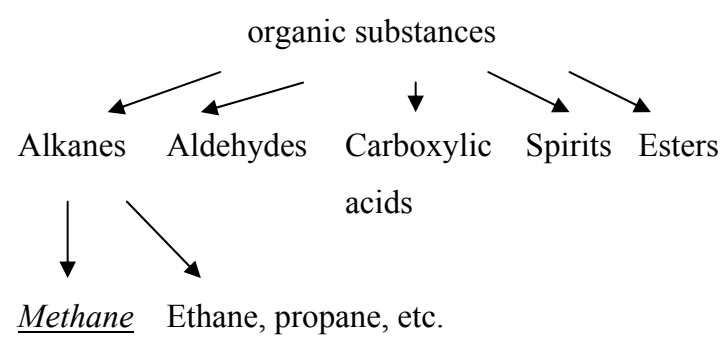

\section{Aerology and ventilation term system}

Harmful occupational factors

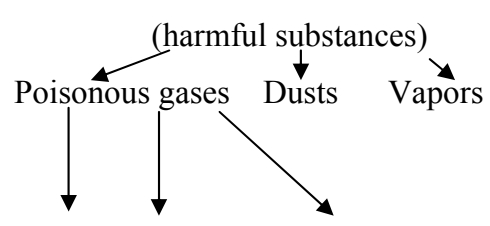

Methane Nitrogen Hydrogen sulphide, oxides etc.

Fig. 1. The difference in the genus-species relations in aerology and ventilation and organic chemistry term systems 
метанодобываемость, метановыделение, метановоздушная (смесь), метановая (зона), метаноемкость, метанометр, метанопылевоздушная смесь, methane-air mixture, methane-air-inert gas mixture, methanometer, methanephone, etc. The main part of these terms denotes properties, equipment or mixtures. The term methane combines with other freemorphemes mainly. But in the chemical term system the term mentioned above combines with the morphemes, which cannot be used independently (suffixes -ol (-ол), -al (-аль)), prefixes (di- (ди-), tri- (три-), tetra- (тетра-)) and free ones. In the first case it forms such terms as метанол, метандиол, метаналь, methanal, methanol, dimethylamine, in the second - хлорметан, дибромметан, chlormethine, tetrabromomethane, etc.

Considerable number of the terms which denote dangerous and harmful substances were also subject to transterminologization. For example, the terms acrylaldehyde (акролеин) and formaldehyde (формальдегид) were taken from organic chemistry term system, the terms hydrogen sulphide (сероводород) and ammonia (аммиак) were transferred from inorganic chemistry term system. Such terms as feeder, blower, nongassy coal mine, high-gas coal mine, explosive limit, explosive dust, gas alarm, суфляр, вентиляциионная установка, взрывчатая пьль, сверхкатегорная махта, внезапный вылрос, выбросоопасный пласт were taken from mining term system, whereas the terms gas-bearing rock, gas zопе, газоносная порода, изогаза were taken from geological term system, etc.

Not only can certain terms come into another term system, but also the groups of words, characterized by hyponymous relationships. It is necessary to point out, that the relations between the terms in such groups do not change as a result of transterminologization. But the whole groups of words which are in a genus-species relationship come into another term system seldom. In many cases only some part of such a group enters and remains in another term system. The number of terms depends on the requirements of the recipient term system, i.e. how many new terms it needs to nominate some notions, objects, etc. (Ryzhenkova, 2001).

For example, medical terms which denote miners' occupational lung diseases (asbestosis, silicosis, pneumoconiosis, асбестоз, силикоз, талькоз, графитоз, сидеросиликоз) сате to the aerology and ventilation term system from the medical one.

But the group of pneumoconioses, caused by the exposure to toxicoallergic aerosols (dusts, which consist of plastic materials and other polymer materials, organic dusts, bioactive substances, etc), is not used in aerology and

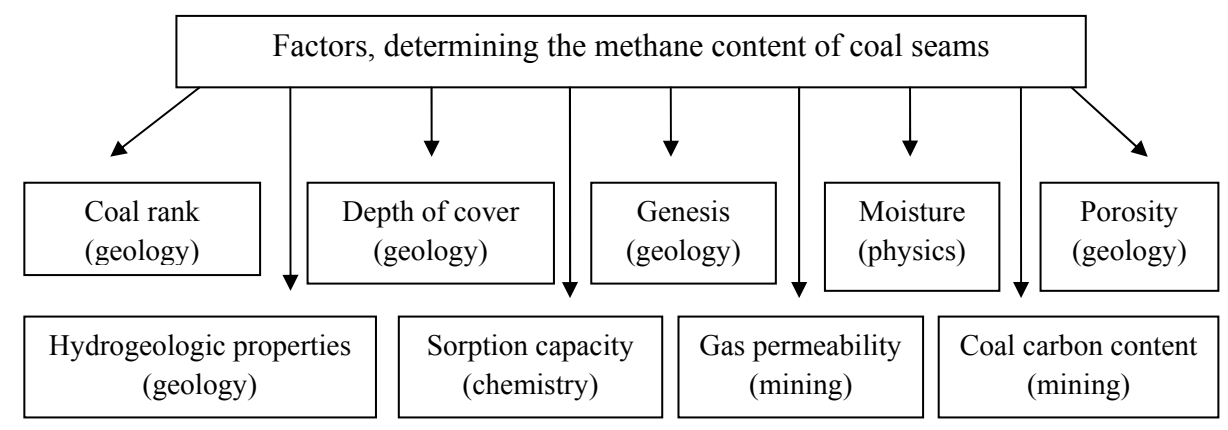

Fig. 2. Microfield structure, which unites the terms, borrowed from geological, mining, chemical and physical term systems 
ventilation term system, as the concepts, which they represent are not relevant for the system. These concepts do not exist in the aerology and ventilation term system.

Besides, the terms and groups of terms which have come from different term systems and terminologies can be united within one group by hyponymous relationships (Ryzhenkova, 2001).

\section{Conclusion}

Thus, the terms which came into aerology and ventilation term system from other term systems underwent the process of transterminologization. Chemical, mining, and geological term systems are the main sources of such terms. When such a term acquires a new definition in the aerology and ventilation term system, an explicit transterminologization takes place. But when the definition remains the same, whereas the structure of the microfield the term enters differs from the initial one, the term is subject to implicit transterminologization. The latter happens more often. In the new term system the borrowed term acquires the ability to combine with bound and free morphemes other than in the initial term system. Very often the borrowed terms join with one or two aerological terms in both English and Russian aerology and ventilation term systems, for example, when such terms as ventilation tubing, intake air opening, air current, вентиляционныйгоризонт, коллектор газа, вентиляиионный ходок, газоотводящая выработка, etc. are formed. The terms, which have any number of components can be subject to transterminologization. The seme composition of the borrowed terms can alter in different ways. For example, an archiseme and / or distinctive semes can change. The change of the whole seme composition takes place seldom.

\section{References}

Baranov, A. N. Vvedeniie v Prikladnuiu Lingvistiku [Introduction to Applied Linguistics]. Moscow, Editorial URSS, 2003. 360 p.

Best Practice Guidance for Effective Methane Drainage and Use in Coal Mines, ECE Energy Series. Available at: http://www.unece.org/fileadmin/DAM/energy/se/pdfs/cmm/pub/BestPractGuide MethDrain_es31.pdf (accessed 3 March 2015).

Cashdollar, K. L., Zlochower, I. A., Green, G. M., Tomas, R. A. \& Hertzberg, M. Flammability of Methane, Propane, and Hydrogen Gases. Available at: http://www.cdc.gov/niosh/mining/UserFiles/ works/pdfs/fompa.pdf (accessed 2 March 2015).

Dictionary of Mining, Mineral, and Related Terms. Compiled and edited by the Staff of the U.S. Bureau of Mines. $2^{\text {nd }}$ Edition. U.S. Department of the Interior, 1996. 3660 p.

Dvoretskii, I. C. Latinsko-Russkii Slovar [Latin-Russian Dictionary]. Moscow, Russian Language Publ., 1976. 1096 p.

Gorbunov, N. I. Teoriia i praktika aerologii gornych predpriiatii [Aerology of Mining Companies: Theory and Practice]. Alchevsk, DonSTU Publ., 2003. 116 p.

Instriktsiia po Degazatsii ugolnich shacht [Instruction for Coal Mine Degassing] (2012). Moscow, ZAO NTTS PB Publ., Series 05. No. 22. 247 p.

Instriktsiia po primeneniiu schem provetrivaniia vyemochnych uchastov ugolnych shacht s izolirovannym otvodom metana iz vyrabotannogo prostranstva s pomoshchiu gazootsasyvaiushchich ustanovok [Instruction for the application of mine workings ventilation schemes in coal mines with isolated methane drainage from the goaf by gas-suction plants (2011). 
Available at: http://www.pravo.gov.ru/proxy/ips/?docbody=\&nd=102156069\&rdk=\&backlink=1 (accessed 3 May 2015)

Kozlovskii, E. A. (chief editor) Gornaia Entsiklopedia [Encyclopedia of Mining]. Vol. 1. Moscow, Soviet Encyclopedia Publ., 1984. 560 p.

Kozlovskii, E. A. (chief editor) Gornaia Entsiklopedia [Encyclopedia of Mining], Vol. 2. Moscow, Soviet Encyclopedia Publ., 1986. 575 p.

Kozlovskii, E. A. (chief editor) Gornaia Entsiklopedia [Encyclopedia of Mining]. Vol. 4. Moscow, Soviet Encyclopedia Publ., 1989. 623 p.

Longman Dictionary of Contemporary English. $3^{\mathrm{d}}$ Edition. Cayfosa-Quebecor. Barcelona, 2001. $1668 \mathrm{p}$.

Paffengolts, K. N. (chief editor) Geologicheskii Slovar [Dictionary of Geology]. Vol. 1. Moscow, Nedra Publ., 1978. 486 p.

Ryzhenkova, T. V. Spetsifika Protsessa Transterminologizatsii v otraslevoi terminosisteme (na Materiale Russkoi I angliiskoi terminologii Pravovedenia) [Peculiarities of Transterminologization Process in an Industry-Specific Term System (based on Russian and English law terminology study)]. Volgograd, Saratov State Law Academy Publ., 2001. 1987 p.

Superanskaia, A. V., Podolskaia, N.V. \& Vasilieva, N.V. Obshchaia Terminologii. Voprosy Teorii [General Terminology. Theoretical Issues]. Moscow, URSS, Librokom Publ., 2012. 248 p.

The Free Online Dictionary. Available at: http://encyclopedia2.thefreedictionary.com/ gravity+flow (accessed 3 May 2015) 


\title{
Транстерминологизация
}

\section{в терминосистеме аэрологии и вентиляции}

\author{
А.А. Телегуз, А.Г. Фомин \\ Кемеровский государственный университет \\ Россия, 650043, Кемерово, ул. Красная, 6
}

Статья посвящена изучению особенностей процесса транстерминологизации терминов-слов и многокомпонентных терминов из терминосистем геологии, химии, горного дела, физики и других наук в терминосистему аэрологии и вентиляции в английском и русском языках. $B$ статье рассматриваются изменения семного состава транстерминологизированных единии, структура микрополей, в которые термины входили до транстерминологизачии и после нее. Определяется возможность данных единии сочетаться с другими терминоэлементами в рамках исходной терминосистемы и терминосистемы-реципиента. Материалом для проведенного исследования послужили русско- и англоязычные тексты по аэрологии карьеров и вентиляции шахт. Проведенный анализ позволяет выяснить преобладающий тип транстерминологизации, установить терминосистемы, из которых перешло наибольшее количество терминов в исследуемую терминосистему, и какого рода изменения произошли в семном составе терминов при транстерминологизации.

Ключевые слова: эксплищитная транстерминологизация, имплицитная транстерминологизация, сема, дифференциальная сема, архисема, семный состав, аэрология.

Научная специальность: 10.00.00 - филологические науки. 